\title{
Geçiş Ekonomilerinde Sağlık Harcamalarının Etkinliği Üzerine Bir İnceleme
}

\author{
An Investigation About Health Spending Efficiency in Transition Economies
}

\author{
Berna BULĞURCU' ${ }^{1}$, PInar ÖZDEMIR²
}

\begin{abstract}
ÖZET
Kaynakların etkin kullanımı, mevcut girdilerle elde edilebilecek en yüksek çıktı düzeyine ulaşmayı ifade eden bir kavramdır. Kaynak tahsis mekanizmasında merkezi planlamacı devletin yerini serbest piyasanın aldığı, kamu mülkiyetinin ise yerini özel mülkiyete bıraktığı eski sosyalist ülkeler, IMF ve Dünya Bankası tarafından geçiş ekonomisi olarak adlandırımaktır. $\mathrm{Bu}$ ülkelerde piyasa sisteminin kurumsallaşması için yapılan düzenlemelerin özellikle sağlık alanında yarattığı etkilerin ölçülmesi, yaşanan dönüşümün etkilerinin belirlenmesinde önemli bir göstergedir. Bu çalışmanın amacl; geçiş süreci boyunca ve sonrasında piyasa sisteminin tesis edilmesinin sağlık harcamalarının etkinliği üzerine etkisini test etmektir. Çalışmada Veri Zarflama Analizi kullanılarak, 2000-2013 yılları arasında ülkelerin etkinlik düzeyleri kıyaslanmıştır.
\end{abstract}

Anahtar Kelimeler: Geçiş Ekonomileri, Sağlık Harcamaları, Veri Zarflama Analizi

\section{GiRiş}

Kaynak tahsis mekanizmasında merkezi planlamacı devletin yerini serbest piyasanın aldığı, kamu mülkiyetinin ise yerini özel mülkiyete bıraktığı eski sosyalist ülkeler, IMF ve Dünya Bankası tarafından "geçiş ekonomisi" olarak adlandırılmaktır. Rudraswamy ve Doggalli (2012)'e göre geçiş ekonomilerinin genel özellikleri: Ekonomik faaliyetlerin liberalleştirilmesinin piyasa mekanizması ile kaynakların en etkin kullanım alanlarına tahsis edilmesi, makroekonomik istikrar için piyasa merkezli dolaylı araçların geliştirilmesi, özelleştirme ile özel girişimlerin etkin yönetiminin sağlanması, etkinliği tesis edecek bütçe kısıtlamalarına sahip ekonomiler olmalarıdır. Yaşanan dönüşüm, eski rejimden miras aldığı milli gelir düzeyini, büyüme oranlarını, eğitim, sağlık, sosyal güvenlik sistemini, politik yapı gibi değişkenlerin benzer özellikler gösterdiği geçiş ekonomilerinin her birini farklı noktalara taşımış durumdadır (Alam vd., 2008; UN Report, 2013; Korkut ve Buzogany, 2013; Chubarova vd., 2013).

Sosyoekonomik birçok dönüşüm geçiren geçiş

\begin{abstract}
"Efficiency" concept means to have maximum output with given input. IMF and World Bank define ex socialist countries as transitions that transform resource allocation mechanism central planning to market system accompined with prefering private property instead of public property. Measurement of institutional changes in order to build market system -especially for health system-is an important indicator to determine affect of transformations. Aim of this study is to analyze affect of building market system on health expenditure during transitions and post transitions period. Data Envelopment Analysis is applied in order to compare transition countries efficiency level for years 20002013.
\end{abstract}

Keywords: Transition Economies, Health Expenditure, Data Envelopment Analysis

ekonomilerinde sağlık politikalarının önemli bir tartışma konusu olmasının nedenlerinden biri bu ülkelerin birçok fırsat ve zorluğa sahip olmalarıdır. Zira geçiş ekonomilerinde fiyatların serbest piyasada belirleniyor olmasının yanında yerelleşme ve özelleştirmenin yarattığı ani değişimlerin geçişin ilk aşamasında ekonomik ve mali krize neden olmuş olması önemli noktalardır. 1989 yılından sonra bu ülkelerde sağlık sisteminin ${ }^{1}$ yaşadığı problemlerle birlikte ölüm oranlarının da artması reform ihtiyacını kaçınılmaz hale getirmiştir. Geçiş ekonomilerinde sağlık politikalarının tartışılmasının diğer önemli bir nedeni ise bu ekonomilerin, merkezi planlamacı sistemden serbest piyasa sistemine geçişte yaşadığı iktisadi zorlukların gerek özel sektörün gerekse kamu sektörünün kıt kaynakların etkin kullanımı konusunda daha özenli davranması gereğinin doğmasıdır (Adeyi vd.,1997; Kutzin, 2010; Nguyen ve Frenk, 2011; Safaei, 2012; Rudraswamy ve Doggalli, 2012).

Sağlık, kalkınmışlık düzeyinin bir göstergesi olup yaşam kalitesini doğrudan etkileyen en önemli faktörlerden biridir. Yürütülen sağlık politikalarından 
umulan toplumdaki bireylerin doğumda beklenen yaşam süresi, bebek ölüm oranları vb. gibi temel sağlık göstergelerinde iyileşmeler yaratması, hizmet alanların memnuniyeti, hizmet sunumunda eşitlik ve mali olarak finansman zorlukları çekenlere de koruma sağlamasıdır. Fakat bunlarla birlikte sağlık sisteminden ve sağlık politikalarından beklenen topluma çağdaş teknoloji içeren, yeterli kapasiteye ve yetkinliğe sahip kaliteli bir sağlık hizmeti sunması gibi hedefleri de yerine getirmesidir. Bu noktada büyük yatırımların yapıldığı sağlık sektörü için kaynakların etkin kullanımının hayati önem taşıyan bir unsur haline gelmiş olduğu açıkça söylenebilmektedir (Kocaman vd., 2015; Smith,2012).

Bu çalışmanın amacl; geçiş ekonomileri kapsamında yer alan Merkezi ve Doğu Avrupa ${ }^{2}$ ülkelerinin geçiş süreci ile birlikte sağlık politikalarında yaşadığı dönüşümü inceleyerek yapılan sağlık harcamalarının etkinliğini ampirik olarak Veri Zarflama Analizi (VZA) ile test etmektir. Çalışmanın ilk bölümünde konu ilgili literatür aktarılarak teorik çerçeve çizilmiştir. Kullanılacak olan ampirik yöntemin ve veri setinin detaylı bir şekilde tanıtıldığı ikinci bölümün ardından üçüncü bölümde ise elde edilen analiz sonuçları ile ülkelerin etkinlik düzeyleri kıyaslanmıştır. Sonuç bölümünde de genel bir değerlendirme yapılarak önerilerle çalışma sonlandırılmıştır.

\section{LITERATÜR ÖZETi}

Bir ülkenin sağlık sisteminden beklenen temel fayda, yönetim (sağlık hizmetlerinin organizasyonu ve düzenlenmesi), finansman (gelir toplama, fonların havuzda toplanması), sağlık hizmetlerinin sunumu, kaynak sağlama (sağlık hizmetlerinin sunumunda kullanılan temel girdilerin temini) işlevlerini yerine getirmesidir. Sağlık sistemleri, temel işlevlerindeki farklılıkları bakımından serbest piyasa, refah yönelimli, kapsayıcı ve sosyalist tipte olmak üzere dört gruba ayrılabilmektedir (Çelebi ve Cura, 2013). Sağlık sistemlerinin örgütlenme yapısındaki bu farklılıklara bağlı olarak sağlık hizmetlerinin sunumu ve üreti$\mathrm{mi}$, muayenehanesinde hizmet sunan hekimler tarafından bireysel olarak yapılabildiği gibi özel sağlık kuruluşları ve kamu sağlık kuruluşlarınca da yapılabilmektedir. Sağlık hizmetlerinin finansmanı da doğrudan ödeme, özel sigorta sistemi, kamusal sigorta sistemi ve vergiler yoluyla gerçekleştirilebilmektedir. Dolayısıyla sağlık hizmetlerinin üretim, sunum ve finansman şekillerinin farklı şekilde örgütleyerek farklı sağlık sistemleri oluşturmak mümkündür. Sağlık sistemini önemli kılan sağlık harcamalarının finansman şeklinin bireyin yaşam kalitesinin, toplum sağlığının ve toplum refahının ana belirleyicisi olmasıdır (Şenatalar, 2003; Yardım vd., 2010). Gupta, Verhoeven ve
Tiongson (2001) sağlık harcamalarının toplumdaki alt ve üst gelir grubu arasındaki farklılıkları kapatmada da önemli bir etkiye sahip olduğunu belirtmektedir. Bu bağlamda devletin tercih ettiği üretim, sunum ve finansman yöntemi ile sağlık alanında ulaşmak istediği temel amaçlar; eşitlik, mikro ekonomik etkinlik, etkililik ve makroekonomik maliyet kontrolüdür. Eşitlik; tüm vatandaşların temel sağlık hizmetlerine erişiminin sağlanması, mikro ekonomik etkinlik; tüketici tatminin en üst düzeye maliyetlerin ise en alt seviyeye de tutulmasıdır. Etkinlik, veri girdi ile daha fazla çıktı elde edilmesi veya veri çıktı miktarına ulaşmak için daha az girdi kullanılması olarak özetlenebilirken, etkililik sağlıkla ilgili temel göstergelerin iyileştirilmesi konusunda belirlenen hedeflere ulaşılması yani nihai amaçların başarılmasıdır. Makroekonomik maliyet kontrolü; milli gelirin sağlık hizmetlerine ayrılan payının belirli bir düzeyde tutulması olarak ifade edilmektedir (Oxley ve MacFarlan, 1996; Mandl, Dierx ve Ilzkovitz, 2008). Sağlık hizmetlerinin sunumundaki etkinlik kavramı; belirlenen amaç ve hedeflere ulaşmak üzere gerçekleştirilen faaliyetlerin bu amaç ve hedeflere ulaşma derecesini belirleyen bir performans boyutu olarak düşünülmektedir (Arslan, 2002). Zira sağlık sektöründe kullanılan tıbbı teknolojinin hızla değişmesi ve emek yoğun bir çalışma alanının olması, sağlığı yüksek maliyetli bir hizmet alanı haline getirirken, etkinlik ölçümlerini (Şahin, 1999) de zorunlu kılmaktadır.

Geçiş öncesi dönemde kaynak tahsis mekanizması merkezi planlama olan Merkezi ve Doğu Avrupa ülkeleri, bu dönemde eşitlik hedefine ulaşmakta başarı göstermişlerdir. Fakat bu ülkelerin kaynak dağılımında etkinliğin sağlanması bakımından aynı sonuca ulaşamadıkları görülmektedir. Bu başarısızlığın en önemli nedenlerinden biri etkinlik ölçümlemeleri konusunda yetersiz kalmalarıdır. Bu noktadan hareketle sosyalist dönemde sağlık sisteminde yaşanan temel sorunlar şu şekildedir (Nruyen ve Frenk, 2011; Stratmann vd., 2010):

Topluma sunulan sağlık hizmetlerine ilaveten ilaçların ücretsiz olarak verilmesi, iyi bir alt yapı tesis edilmesine rağmen bürokrasi ve planlamanın katı bir şekilde uygulanmasına bağlı olarak hizmet kalitesinin sınırlandırılması ve böylelikle tam kapasite kullanımının engellenmiş olması.

$>\quad$ Nitelik değil niceliğin önemsenmesi ve bu durumun fiziki alt yapı ve sağlık personelinin performansı üzerinde olumsuz etki yaratması.

$>$ Devlet bütçesinden finanse edilen sağlık sektörünün katı bir şekilde merkezi otoriteye bağlanmış olması yerel ihtiyaçların karşılanmasında yetersizlik yaratması. 
$>$ Kaynakların etkin kullanımının özendirilmemesi ile sağlık hizmetleri yerine tedavi edici hizmetlerin ağırlık kazanması. Yerinde ve zamanında tedavi olmak isteyen hastalar gayrı resmi ödeme yapma yoluna başvurmaya başlamış olması.

Geçiş sonrası dönemde bu ülkelerde mali göstergelerin bozulması ve kamu fonlarının azalması sağlık hizmetlerinin sunumunu da etkilemiştir. Halk tarafından talep edilen sağlık hizmeti ile arz edilen sağlık hizmetleri arasında oluşan boşluk hizmet standartlarını düşürerek gayri resmi ödemeleri yaygınlaştırmıştır. Merkezi planlamacı dönemde fiyat mekanizmasının olmamasının toplumda takas usulünün yani yapılan hizmete karşı hizmet sunma veya hediye verme gibi gayri resmi uygulamaların yer edinmiş olmasının etkisi yeni dönemde de gözlenmektedir (Ensor, 2004).

Merkezi ve Doğu Avrupa Ülkeleri sağlık alanında geçişin farklı evrelerinde finansman kaynaklarından (kullanıcı katkılarının özel sağlık sigortalarının sisteme dahil edilmesi), idare şekline (hastane yönetimin özerklik kazanması), hizmeti sunum şeklinden kaynakların geliştirilmesine (çalışanların niteliğini arttırıcı önlemler alınması) kadar birçok reform yapmıştır. Reform sonrası dönemde sosyoekonomik göstergelerin iyileşmesi bakımından Batı Avrupa standartlarına en çok yaklaşan yine bu ülkeler olmuştur. Bugün kamu ve özel sektörün karmasından oluşan bir sosyal güvenlik sistemi ile zorunlu cepten ödemeleri ikame yerine tamamlayıcı olarak kullanan özgün bir sağlık sistemi tesis edebilmişlerdir (Wagener, 2011).

Geçiş sonrası dönemde Avrupa Birliği üyesi olan bu ülkelerde farklı sağlık politikaları uygulanmasında Avrupa Birliği'nin 2007 yılına kadar ortak bir sağIık politikası geliştirmemiş olması da etkili olmuştur.
Avrupa Birliği, bu tarihten itibaren sağlık sistemi ve teknolojilerini geliştirmek üzere bir strateji belgesi geliştirmiştir. Avrupa Birliğince hazırlanan komisyon raporunda ülkelerin sağlık sistemlerinin incelenmesi, farklılıklarının ortaya konması yanında maliyet etkinliği problemlerinin çözümü için yardım stratejileri geliştirilmiştir (Paoli, 2012).

Geçiş sonrası dönemde Merkezi ve Doğu Avrupa ülkelerinde sağlık alanında yaşanan dönüşümün etkileri üzerine istatistiksel ve ekonometrik yöntemler kullanılarak uygulamalı çalışmalar da yapılmıştır. Bu çalışmalardan Fakin ve Crombrugghe (1997), Evans vd. (2001) Kumbhakar (2004), Mirmirani (2008), Stratmann vd. (2010), Safaei (2012), Tambori vd. (2013), Carvalho vd. (2013)'nun kullandığı veri seti, değişkenler, yöntem ve elde ettikleri temel bulgular Tablo 1'de gösterilmektedir.

Bu çalışmaların dikkat çeken en önemli yanı geçiş sonrası dönemde meydana gelen değişimin etkisindeki ülkelerin sağlık alanında yaşanan dönüşümden nasıl etkilendikleri üzerine incelemeler olmalarıdır. Literatür taraması genel olarak incelendiğinde sağlık sistemlerinin etkinliğini ölçmek adına gerçekleştirilen pek çok farklı çalışma bulmak mümkündür. $\mathrm{Bu}$ çalışmalara örnek olarak Hollingsworth vd.(1999); Linna vd. (2003), Kayal vd. (2004), Retzlaff-Roberts vd. (2004), Puenpatom ve Rosenman (2006), Jacobs vd. (2006), Kirigia vd. (2007), Masiye (2007), Joumard vd. (2010), Zhang vd. (2007) ve Popescu vd. (2014)'nin çalışmaları verilebilir. Ancak geçiş ekonomili ülkelerin sağlık harcamalarının bileşim ve finansman yöntemlerinde yaşanan dönüşümün etkilerinin irdelendiği literatür kısıtlıdır. 
Tablo 1: Sağlık Harcamalarının Etkinliğinin Ölçülmesi ile İlgili Literatür

\begin{tabular}{|c|c|c|c|c|}
\hline Yazarlar & Veri Seti & Veriler & Yöntem & Temel Bulgular \\
\hline $\begin{array}{l}\text { Fakin ve } \\
\text { Crombrugghe } \\
\text { (1997) }\end{array}$ & $\begin{array}{l}\text { Doğu Avrupa } \\
\text { Ülkeleri } \\
1992\end{array}$ & $\begin{array}{l}\text { Girdi: Kamu sağlık harcamaları } \\
\text { Çıktı: Patent, üniversiteye giriş, bebek } \\
\text { ölüm oranları, beklenen yaşam süresi, } \\
\text { yaşıı demografik bağımlılık oranı, ana } \\
\text { telefon hattı sayısı }\end{array}$ & $\begin{array}{l}\text { Non parametrik } \\
\text { girdi çıktı analizi }\end{array}$ & $\begin{array}{l}\text { Kamu harcamalarının } \\
\text { azaltılması ve yeniden } \\
\text { yapılandırılması ile etkinliği } \\
\text { arttırır. }\end{array}$ \\
\hline Evans vd. (2001) & $\begin{array}{l}191 \text { ülke } \\
\text { 1991-1997 }\end{array}$ & $\begin{array}{l}\text { Girdi: Kişi başına sağlık harcaması, gelir } \\
\text { düzeyi ve eğitim harcamaları } \\
\text { Çıktı:Bebek ölüm oranları, tedavi olan } \\
\text { hasta sayısı }\end{array}$ & $\begin{array}{l}\text { Panel veri } \\
\text { Deterministik } \\
\text { stokastik sınır } \\
\text { modelleri }\end{array}$ & $\begin{array}{l}\text { Kişi başına sağlık harcamaları } \\
\text { arttıkça etkinlik artar. Ülke } \\
\text { koşulları önemli bir etkendir. }\end{array}$ \\
\hline $\begin{array}{l}\text { Kumbhakar } \\
(2004)\end{array}$ & $\begin{array}{l}141 \text { ülke } \\
1993-1997\end{array}$ & $\begin{array}{l}\text { Girdi: Kişi başına sağlık harcamaları, } \\
\text { okullaşma oranı } \\
\text { Çıktı: Ortalama yaşam süresi }\end{array}$ & $\begin{array}{l}\text { Panel veri Stokastik } \\
\text { sınır yaklaşımı }\end{array}$ & $\begin{array}{l}\text { Heterojenliğe neden olan, } \\
\text { etkinsizlik yaratan değişkenler } \\
\text { tespit edilmiştir. }\end{array}$ \\
\hline $\begin{array}{l}\text { Mirmirani } \\
(2008)\end{array}$ & $\begin{array}{l}\text { Geçiş } \\
\text { ekonomileri } \\
\text { 1997-2001 }\end{array}$ & $\begin{array}{l}\text { Girdi. Kişi başına sağlık harcaması, } \\
\text { ayakta tedavi görenlerin toplam nüfusa } \\
\text { oranı, doktorların toplam nüfusa oranı, } \\
\text { aşılamalar } \\
\text { Çıktı: Ortalama yaşam süresi ve bebek } \\
\text { ölüm oranları }\end{array}$ & Veri zarflama analizi & $\begin{array}{l}\text { Ülkeler kaynak kullanımında } \\
\text { etkinlik durumlarına göre } \\
\text { sıralanmıştır. }\end{array}$ \\
\hline $\begin{array}{l}\text { Stratmann vd. } \\
\text { (2010) }\end{array}$ & $\begin{array}{l}\text { OECD ülkeleri } \\
\text { 1990-2007 }\end{array}$ & $\begin{array}{l}\text { Bağımlı değişken: Kişi başına kamu sağlık } \\
\text { harcamaları Bağımsız değişkenler: Mali } \\
\text { dengesizlik indeksi, borçlanma, ülke } \\
\text { spesifik değişkenler }\end{array}$ & Panel veri analizi & $\begin{array}{l}\text { Cepten ödemeler etkinliği } \\
\text { olumlu etkilemektedir. }\end{array}$ \\
\hline Safaei (2012) & $\begin{array}{l}\text { M. ve Doğu } \\
\text { Avrupa } \\
\text { Ülkeleri 1990- } \\
2009\end{array}$ & $\begin{array}{l}\text { Bağımlı değişken: Ölüm oranları veya } \\
\text { ortalama yaşam beklentisi } \\
\text { Bağımsız değişkenler: Kişi başına gelir, } \\
\text { açıklık indeksi, demokrasi indeksi }\end{array}$ & Panel veri analizi & $\begin{array}{l}\text { Yükselen gelir ile açık toplum } \\
\text { olmak pozitif, ölüm oranları } \\
\text { negatif ilişkiye sahiptir. }\end{array}$ \\
\hline $\begin{array}{l}\text { Tambori vd. } \\
\text { (2013) }\end{array}$ & $\begin{array}{l}\text { Bulgaristan, } \\
\text { Macaristan, } \\
\text { Litvanya, } \\
\text { Polonya, } \\
\text { Romanya ve } \\
\text { Ukrayna } \\
2010 \\
\end{array}$ & $\begin{array}{l}\text { Bağımlı değişken: Sağlık harcamalarının } \\
\text { finansman şekli (cepten, borçlanarak vb.) } \\
\text { Bağımsız değişkenler: Yaş, cinsiyet, } \\
\text { eğitim, yerleşim, hane halkı geliri, sağlık } \\
\text { sigortasının durumu, sağlık durumunda } \\
\text { kişinin kendi algısı ve kronik hastalıkların } \\
\text { teşhisi }\end{array}$ & $\begin{array}{l}\text { Logit ve } \\
\text { multinominal } \\
\text { lojistik regresyon }\end{array}$ & $\begin{array}{l}\text { Sağlık hizmetleri talebinde } \\
\text { kişinin kendi finansmanını } \\
\text { yapması ağırlık kazanmaktadır. }\end{array}$ \\
\hline $\begin{array}{l}\text { Carvalho vd. } \\
\text { (2013) }\end{array}$ & $\begin{array}{l}25 \text { Geçiş } \\
\text { Ekonomisi } \\
1992-2007\end{array}$ & $\begin{array}{l}\text { Bağımlı değişken:insani gelişme indeksi } \\
\text { Bağımsız değişkenler: Büyük ve } \\
\text { küçük ölçekli özelleştirmeler, girişim, } \\
\text { rekabetçilik, bankacılık ve ticaret yapma } \\
\text { özgürlü indeksleri }\end{array}$ & Panel veri analizi & $\begin{array}{l}\text { Özelleştirmeler insani gelişme } \\
\text { üzerinde negatif etkiye } \\
\text { sahiptir. }\end{array}$ \\
\hline
\end{tabular}

\section{GEÇIŞ EKONOMILERINDE SAĞLIK SISTEMININ ETKINLIK ANALIZi}

Sosyalist Sovyetler Cumhuriyeti Birliği (SSCB)'nin dağılmasından sonra Merkezi ve Doğu Avrupa ülkeleri, yaşanılan ekonomik ve mali krizi aşmak ve piyasa ekonomisine geçişte ayakta kalabilmek adına hükümet harcamalarının önceliğinde değişiklikler yapmışlardır. Sağlık harcamalarında meydana gelen değişimlerle birlikte farklılaşan sağlık sisteminin yeni yapısı piyasa ekonomisi zihniyeti ile değişen sayısız ekonomik ve sosyal değişiklikler arasındaki yerini almıştır. Değişen bu yapının sağlık sistemi üzerindeki etkisinin incelenmesi adına geçiş ekonomili ülkeler arasından özellikle de Avrupa Birliği'ne kabul edilen ülkelerin sağlık sistemlerinin etkinliğinin incelenmesi için Veri Zarflama Analizi tekniğinden yararlanılmıştır. Ülkeler arasında etkinlik kıyaslaması yapılmasının temel nedeni Tablo 1'de de görüldüğü üzere literatürde geçiş sürecini tamamlayan ülkeler üzerine herhangi bir incelemenin yapılmamış olmasıdır. Dünya Bankası'nın 2008 yılına ait yayınlanan Unleashing Prosperity:Productivity Growth in Eastern Europe and the Former Soviet Union başlıklı refah konulu raporda bahsedildiğine göre; geçiş ekonomili ülkelerden Bulgaristan, Çek Cumhuriyeti, Estonya, Letonya, Litvanya, Macaristan, Polonya, Romanya, Slovakya, Slovenya AB üyesi oldukları tarihten itibaren ki bu tarihler 2004 ve 2010 yıllarıdır, piyasa ekonomisine geçişlerini tamam- 
lamış durumda ülkeler olarak kabul edilmektedirler. Bu nedenle bu ülkelerin sağlık harcamaları üzerine etkinlikleri analiz edilerek piyasa ekonomisine geçiş süreci ve sonrasında sağlık sistemlerinde meydana gelen değişikliklerin etkinlik düzeylerinde yıllar itibariyle herhangi bir etki yaratıp yaratmadığı tespit edilmek istenmiştir. Bu tespitler ülkeler arası göreceli performans karşılaştırmaları ile desteklenerek ortaya konulmaya çalışılmıştır.

\subsection{YÖNTEM}

Veri Zarflama Analizi (VZA) çoklu girdi ve çıktıya dayanan çoklu karar verme birimlerinin göreceli etkinliğini hesaplayan matematik tabanlı bir tekniktir (Liu vd., 2000). Illk olarak Charnes, Cooper ve Rhodes (1978) tarafından geliştirilen bu matematiksel modelin temeli benzer karar birimleri arasındaki girdi ve çıktıları esas alan göreceli bir teknik etkinlik hesabıdır. Tıp, eğitim, üretim, benchmarking, uzay çalışmaları, spor, işletme çözümleri, toptancı mağazalar, bankacılık, yer seçimi, silahlı kuvvetler, fast-food restoranlar, bölgesel kalkınma gibi konularda uygulama alanı bulan VZA'nın en karakteristik özelliklerinden biri doğrusal programlama prensibine dayanıyor olmasıdır ki ayrıca birden çok girdi ve çıktıyı birlikte dikkate alma imkanı tanıması da bir başka önemli özelliğidir. Girdi ve çıtıların farklı birimlerden oluşabilmesine ve her bir karar biriminin yalnızca en iyi karar birimi ile karşılaştırabilmesine imkan sunan bir teknik olması ile de etkinlik değerlendirmesi yapan diğer tekniklerden ayrılmaktadır.

VZA'da ölçeğe göre sabit getiri ile analiz yapan bir yöntem olan CCR (Charnes-Cooper-Rhodes) modeli ile 1984 yılında Banker-Charnes-Cooper tarafından geliştirilen ölçeğe göre değişken getiri varsayımı altında analiz yapan BCC modeli temel modeller olarak kabul edilmektedir. VZA ile etkinlik analizinde hangi modele başvurulacağı yapılacak araştırmanın niteliğine göre farklılık göstermektedir. Geçiş ekonomili ülkelerin karar verici birimleri temsil ettiği bu çalışmada sağlık harcamalarının teknik değil toplam etkinliğinin elde edilmesi hedeflendiği için bu hedefe uygun, toplam etkinlik ölçümünün bir parçası olan ölçeğe göre sabit getiri varsayımı altında analiz yapılmıştır. Bu varsayım altında gerçekleştirilecek etkinlik analizine en uygun model de CCR modeli olduğu için bu model tercih edilmiştir. CCR modelinin iki farklı türü bulunmaktadır. Bunlardan ilki mevcut bulunan çıktı seviyesini karşılayabilecek şekilde girdileri minimize etmeyi amaçlayan girdi-odaklı model, bir diğeri ise mevcut girdilerden daha fazlasını talep etmeyecek şekilde çıktıları maksimize etmeyi amaçlayan çıktı-odaklı modeldir. Bu çalışmada girdi odaklı CCR modeli tercih edilmiştir. Bunun en önemli nedeni ülkelerin çıktıyı kontrol etme veya üzerinde değişiklik yapma güçlerinin girdi üzerinde değişiklikler yapabilme güçlerine kıyasla daha sınırlı olmasıdır. Çıktılar sabit tutulurken girdi değerlerinin azaltıldığı bir sağlık sisteminin yıllar itibariyle piyasa ekonomisine geçiş süreci boyunca ve sonrasında etkin olup olmadığının değerlendirilmesi için en uygun modelin girdi odaklı CCR modeli olduğu kanaatini destekleyen benzer çalışmalar da bulunmaktadır. Bu çalışmalar arasında özellikle 2008 yılında Mirmirani'nin OECD ve geçiş ekonomili ülkelerin sağlık sistemlerinin etkinliğini girdi odaklı CCR modeli kullanarak karşılaştırması dikkat çekmektedir. Çünkü Mirmirani, bu modelin sağlık sistemini yöneten politik güçler için de en uygun yöntem olduğunu tespit etmiştir.

Girdi odaklı CCR modelin doğrusal programlama formülasyonu şu şekildedir:

$$
\operatorname{Max} e_{0}=\sum_{r=1}^{s} u_{r} Y_{r o}
$$

\section{Sınırlayıcı Şartlar:}

$$
\begin{aligned}
& \sum_{r=1}^{s} u_{r} y_{r j}-\sum_{i=1}^{m} v_{i} x_{i j} \leq 0 \\
& \sum_{i=1}^{m} v_{i} x_{i o}=1 \quad u_{r, v_{i}} \geq 0 \\
& \lambda_{j} \geq 0 \quad j=1, \ldots \ldots n \\
& r=1, \ldots \ldots . s \quad i=1, \ldots \ldots m
\end{aligned}
$$

Modelde kullanılan semboller aşağıdaki şekilde tanımlanmaktadır.

$u_{r}$ : o'uncu karar verme birimi tarafından r'inci çıktıya verilen faktör ağırlığı,

$Y_{r o}$ : Etkinliği ölçülen o'uncu karar verme birimine ait r'inci çıktı miktarı,

$y_{r j}$ :j'inci karar verme biriminin kullandığı r'inci çıktı miktarı,

$x_{i j}$ :j'inci karar verme biriminin kullandığı i'inci girdi miktarı,

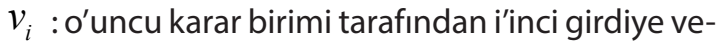
rilen faktör ağırlığı,

$x_{i o}$ : Etkinliği ölçülen o'uncu karar verme birimine ait i'inci girdi miktarı.

Her bir ülke yani karar verici birim için analiz edilecek her bir yıl için $\mathrm{n}$ adet matematiksel model oluşturularak modeldeki kısıtlar aynı kalacak şekilde 
amaç fonksiyonları tek tek hazırlanmaktadır. Modelin çözümü için her bir karar birimi kendi toplam etkinliğini maksimum kılacak ağırlıkları girdiler için $v_{1 k}$, $v_{2 k}, v_{3 k}$ ve $v_{4 k}$; çıktılar için $u_{1 k}$ ve $u_{2 k}$ sembollerini kullanarak belirledikten sonra bu ağırlık değerleri kullanılarak optimum etkinlik değeri olan $e_{0}$ elde edilir. Eğer $e_{0}$ değeri 1'den küçük tespit edilirse karar verici birim yani o ülke için CCR etkinsizdir diye ifade edilir. Bu değerin 1'e eşit olması durumunda karar verici birim için CCR etkindir denilmektedir. Bu modellerin elle çözülmesi veri setinin büyüklüğü nedeniyle tercih edilmemiş ve VZA için geliştirilen yazılımlardan biri olan DEA Solver Pro 4.1. yazılımından destek alınarak araştırmanın bulguları elde edilmiştir.

\subsection{VERI SETi}

Girdi değerlerinin azaltıldığı bir sağlık sisteminin yıllar itibariyle piyasa ekonomisine geçiş süreci ve sonrasında etkin olup olmadığının değerlendirilmesi adına literatürde farklı çalışmadan yararlanılarak pek çok girdi ve çıktı değişkeni belirlenmiştir. Bu girdi ve çıktılar çalışmanın veri setini oluşturmaktadır. Ancak bazı verilerin elde edilmesi konusundaki bir takım kısıtlar ve VZA'nın önemli şartlarından biri olan girdiçıktı sayısı ve karar verici birim sayısı arasında dikkat edilmesi gereken denge göz önünde bulundurularak literatürde sağlık harcamaları konusunda en sık kullanılan girdi ve çıtı değişkenleri belirlenmiştir. $m$ girdi sayısı, s çıktı sayısı ve $\mathrm{N}$ karar verici birim sayısı olarak kabul edildiğinde bu sayılar arasındaki dengenin VZA yönteminde ne olması gerektiği konusundaki görüşlerden (Sherman ,1984; Boussofianee vd, 1991; Cooper vd., 2001) arasından en güncel olan Dyson ve arkadaşlarının 2001 yılında yaptıkları çalışmadaki görüş baz alınarak denge $N \geq 2 m+s$ formülü ile sağlanmıştır. Böylelikle seçilen girdi ve çıktı değişkenlerinin etkinlik analizindeki güçleri arttırılmıştır.

Bu güçleri artan ve geçiş ekonomili ülkelerin sağlık harcamalarının etkinliğini belirlemede sıklıkla kullanılan değişkenler Tablo 2'de gösterildiği gibidir.

Tablo 2: Girdi ve Çıktı Değişkenleri

\begin{tabular}{|l|l|}
\hline \multicolumn{1}{|c|}{ Girdi Değişkenleri } & \multicolumn{1}{|c|}{ Çıktı Değişkenleri } \\
\hline Bin kişi başına düşen doktor sayısı & \\
Bin kişi başına düşen hastane yatağı sayısı & Beklenen Yaşam Süresi \\
Kişi başına düşen sağlık harcaması (\$) & Bebek Ölüm Oranı (Tersi-\%) \\
Bağışıklık kazandırma oranı (\%) & \\
\hline
\end{tabular}

Doktor ve hastane yatağı sayısı ülke nüfusuna bağlı olduğundan ve buna göre değişiklik göstereceğinden dolayı bin kişi başına düşen doktor ve hastane yatağı sayısı olarak ele alınmıştır. Kişi başına düşen sağlık harcamaları ise her türlü sağlık hizmeti sağlama, aile planlama, beslenme aktiviteleri, acil servis yardımlarını da kapsayan bir değişken olarak 2005 yılı uluslararası alım gücü oranları göz önünde bulundurularak ABD dolarına karşııık gelecek şekilde düzenlenmiş olan rakamlar şeklinde kullanılmıştır. Son girdi değişkeni ise ülkelerin bağışıklık kazandırma oranlarıdır. Bu oran kızamıkçık enfeksiyonuna karşı bağışıklık geliştirmek adına kızamıkçık aşısı olan 12-23 aylık çocukların yüzdesi şeklinde ele alınmıştır. Çıktı değişkeni olarak seçilen değişkenlerden ilki doğumdan itibaren beklenen toplam yaşam süresi iken diğer değişken ise her bin doğumda meydana gelen ölüm oranını gösteren bebek ölüm oranıdır. Beklenen yaşam süresinin pozitif etkisi göz önünde bulundurularak değerlendirme öncesi bebek ölüm oranının tersi alınmış ve analize dahil edilmiştir.

Kısaca girdi ve çıktı değişkenlerine ait veriler Dünya Bankasının veri tabanından elde edilmiştir. $A B^{\prime} y e$ üyeliği gerçekleşmiş geçiş ekonomisine tabi olan 10 ülkenin 2000-2013 yılları arasındaki girdi ve çıktı de- ğişkenlerinin değerleri ile matris oluşturulmuştur. Bu matrisler daha önce de bahsedilen özel bir yazılım kullanılarak girdi odaklı CCR modeline uygun şekilde analiz edilerek bulgular elde edilmiştir.

\section{BULGULAR}

2008 yılında Dünya Bankası yayınladığı bir raporda 2007 yılında Romanya ve Bulgaristan'ın da AB'ye üye olması ile birlikte ikinci bir dalganın tamamlandığını ve böylelikle 2004 yılında AB'ye üye olan Çek Cumhuriyeti, Estonya, Litvanya, Letonya, Macaristan, Polonya, Slovenya, Slovakya ile birlikte bu ülkeler için piyasa ekonomisine geçişin tamamlandığı vurgusu yapmıştır. Bu rapordan yola çıkılarak 2007 yılı milat kabul edilmiş ve SSCB'nin dağılmasının yarattığı etkinin devam ettiği ve piyasa ekonomisine geçiş süreci olarak da kabul edilen 2000-2006 yılları arasındaki 7 yıllık dönemde ülkelerin var olan sağlık sistemlerinin durumu ortaya konarak ülke kıyaslaması yapılmıştır. Tüm bunlara ilaveten 2007-2013 yılları arasında piyasa ekonomisine geçildikten sonraki dönemde sağlık sisteminde bir değişiklik olup olmadığı da ortaya konularak sağlık sistemi etkin ve etkin olmayan ülkeler sıralanmıştır. Illk dönem olarak kabul edilen 2000-2006 arasındaki dönemde ülkelerin etkinlik skorları Tablo 3'de görüldüğü gibidir. 
Tablo 3: Ülkelerin 2000-2006 Yılları Arası CCR Modeline Göre Etkinlik Değerleri

\begin{tabular}{|c|c|c|c|c|c|c|c|}
\cline { 2 - 8 } \multicolumn{1}{c|}{} & $\mathbf{2 0 0 0}$ & $\mathbf{2 0 0 1}$ & $\mathbf{2 0 0 2}$ & $\mathbf{2 0 0 3}$ & $\mathbf{2 0 0 4}$ & $\mathbf{2 0 0 5}$ & $\mathbf{2 0 0 6}$ \\
\hline Bulgaristan & 1 & 1 & 1 & 0,99122 & 1 & 0,99916 & 0,98955 \\
\hline Çek Cumhuriyeti & 1 & 1 & 0,99288 & 0,97494 & 0,9846 & 0,98303 & 1 \\
\hline Estonya & 1 & 1 & 1 & 1 & 1 & 1 & 1 \\
\hline Letonya & 0,91706 & 0,93211 & 0,94526 & 0,94959 & 0,94686 & 0,98185 & 0,96194 \\
\hline Litvanya & 0,92208 & 0,95960 & 0,95746 & 0,95455 & 0,96013 & 0,96123 & 0,94883 \\
\hline Macaristan & 0,89861 & 0,91155 & 0,91800 & 0,92068 & 0,92445 & 0,92452 & 0,93369 \\
\hline Polonya & 1 & 1 & 1 & 1 & 1 & 1 & 1 \\
\hline Romanya & 1 & 1 & 1 & 1 & 1 & 1 & 1 \\
\hline Slovakya & 0,94571 & 0,94760 & 0,96266 & 0,97494 & 0,95547 & 0,96724 & 0,96351 \\
\hline Slovenya & 1 & 1 & 1 & 1 & 1 & & 1 \\
\hline
\end{tabular}

Tabloda verilen etkinlik değerlerine göre geçiş ekonomili ülkeler arasından Estonya, Polonya, Romanya ve Slovenya 2000-2006 yılları boyunca sağlık sistemlerini etkin bir şekilde yöneten ülkeler olarak tespit edilmiştir. Ayrıca bu ülkeler sahip oldukları etkinlik değerleri ile etkin sınır üzerinde bulunmayan diğer ülkelere de referans olabilecek nitelikte birer ülke olduklarını göstermişlerdir. Referans ülke kavramının kullanım amacı piyasa ekonomisine geçiş sürecinin sağlık sektörü boyutunda yürütülecek stratejilerin belirlenmesine yardımcı olmaktır. Etkin olmayan ülkelerin hangi girdileri ne kadar artırıp azaltacağı konusunda kullanılan $\lambda$ yoğunluk değerleri de göz önünde bulundurularak hesaplamalar yapılmıştır. $\mathrm{Bu}$ hesaplamalarda kullanılan referans ülkeleri ve yoğunluk değerleri Ek 1'de tablo olarak verilmiştir. Bu değerler etkin olmayan ülkelerin etkin hale getirilebilmesi için gerekli olan iyileşme derecelerinin hedef değerlerinin hesaplanmasına olanak sağlayan benimsenen stratejiye yön veren değerlerdir. 2000 yılı için sağlık sistemini diğer ülkelere göre en başarısız bir şekilde yöneten ülke olan Macaristan'ın gerçekleşen değerleri ve doğrusal programlama yöntemi ile hesaplanan hedeflenen değerleri Tablo 4'de görüldüğü gibidir.

Tablo 4: Macaristan'a Ait 2000 Yılı Girdileri için İyileştirme Değerleri

\begin{tabular}{|l|c|c|c|c|}
\hline & Gerçekleşen & Hedef & Fark & $\%$ \\
\hline Bin kişi başına düşen doktor s. & 3,2 & 2,875581392 & $-0,324418608$ & $-10,14 \%$ \\
\hline Bin kişi başına düşen hastane yatağı s. & 8,100000382 & 6,519263946 & $-1,580736435$ & $-19,52 \%$ \\
\hline Kişi başına düşen sağlık harcaması & 851,8512479 & 757,4174855 & $-94,43376237$ & $-11,09 \%$ \\
\hline Bağışıkık kazandırma oranı & 99 & 88,96329931 & $-10,03670069$ & $-10,14 \%$ \\
\hline
\end{tabular}

Macaristan'ın 2000 yılında bin kişi başına düşen doktor sayısı ortalamanın altında iken hastane yatağı sayısı ile kişi başına düşen sağlık harcamaları da ortalamanın hayli üstünde çıkmıştır. Bağışıklık kazandırma oranı ise yine ortalamanın üstündedir. Bu şekilde kullanılan girdilerin değerlendirilmesi sonucu VZA'nın ortaya koyduğu rakamlar karar verici mekanizmalara öneri mahiyetindedir. Macaristan'ın sağlık alanında yeni sisteme ayak uydurabilmek adına bin kişi başına düşen doktor sayısını \%10,14 oranında ve bin kişi başına düşen hastane yatağı sayısını \%19,52 oranında azaltması önerilmiştir. Piyasa ekonomisinin gerektirdikleri düşünüldüğünde kişi başına düşen sağlık harcamalarının \%11,09 oranında ve bağışıklık kazandırmada kızamıkçık aşısı vurdurma oranlarının \% 10,14 şeklinde azaltılması önerisi şaşırtıcı değildir. 2007 yılı öncesi dönemde geçiş ekonomili ülkeler arasında bebek ölüm oranının düşürülmesi ve beklenen yaşam süresinin artırılması açısından bu girdi değişkenleri üzerinde gerçekleştirilecek değişiklikler önemli görülmektedir. 2000 yılında etkin olmayan diğer geçiş ekonomili ülkelerin iyileştirme tabloları Ek 3'de verilmiştir.

Girdi odaklı modellerin tasarruf bazlı modeller olması ve bunun yanında kamuda devletin yaptığı tasarrufların önem taşıması ile de en az girdiyle en iyi çıktı değeri elde edilmesinin anlamı etkin kullanımın var olduğudur. 2007 öncesi döneme kadar SSCB'nin dağılmış olmasının etkilerinin halen görüldüğü ve küresel pazarda yer bulmak adına geçiş sürecini tamamlamaya çalışan bazı geçiş ekonomili ülkelerin 2004 yılında $A B^{\prime}$ ye üye olmayı başarmış oldukları görülmektedir. Ancak bu üyeliğe rağmen geçiş ekonomili ülkeler kategorisinde değerlendirilmeye alınmaya devam etmişlerdir, ta ki 2008 yılında Dünya Bankası'nın yayınladığı ülkelere ait refah konulu raporda geçiş 
sürecinin artık tamamlandığı ibaresi yer alana kadar. Bu nedenle 2007 yılı öncesi dönemde sağlık sistemlerinin nasıl olduğu yönünde değerlendirmede bulunulan ülkelerin geçiş süreci tamamlandıktan sonraki dönem olan 2007-2013 yılları boyunca sağlık sistemlerinin etkinliğinin 2007 yılı öncesi dönemden çok da farklı sonuçlar elde etmediği tespit edilmiştir.

Tablo 5: Ülkelerin 2007-2013 Yılları Arası CCR Modeline Göre Etkinlik Değerleri

\begin{tabular}{|c|c|c|c|c|c|c|c|}
\cline { 2 - 8 } \multicolumn{1}{c|}{} & $\mathbf{2 0 0 7}$ & $\mathbf{2 0 0 8}$ & $\mathbf{2 0 0 9}$ & $\mathbf{2 0 1 0}$ & $\mathbf{2 0 1 1}$ & $\mathbf{2 0 1 2}$ & $\mathbf{2 0 1 3}$ \\
\hline Bulgaristan & 0,99923 & 1 & 0,99172 & 0,96168 & 0,95065 & 0,97341 & 0,96461 \\
\hline Çek Cumhuriyeti & 0,99001 & 1 & 0,96814 & 0,96601 & 0,95901 & 0,95555 & 0,93864 \\
\hline Estonya & 1 & 1 & 1 & 1 & 1 & 1 & 1 \\
\hline Letonya & 0,94533 & 0,99902 & 0,96276 & 1 & 1 & 1 & 0,94055 \\
\hline Litvanya & 0,94712 & 0,95607 & 0,96733 & 0,95455 & 0,94471 & 0,96710 & 0,96551 \\
\hline Macaristan & 0,94179 & 0,95189 & 0,94031 & 0,92275 & 0,90819 & 0,93333 & 1 \\
\hline Polonya & 1 & 1 & 1 & 1 & 1 & 1 & 0,97373 \\
\hline Romanya & 1 & 1 & 1 & 1 & 1 & 1 & 1 \\
\hline Slovakya & 0,94642 & 0,94875 & 0,93131 & 0,92834 & 0,92824 & 0,92545 & 0,93182 \\
\hline Slovenya & 1 & 1 & 1 & 1 & 1 & 1 & 1 \\
\hline
\end{tabular}

Tablo 5'de de görüldüğü üzere Estonya, Romanya, Polonya ve Slovenya, 2007 yılı öncesi dönemde olduğu gibi yine etkinliğini devam ettiren ülkeler olarak tespit edilmiştir. Letonya ise $7 \mathrm{yıl} \mathrm{öncesine} \mathrm{göre} \mathrm{sağlık}$ sistemini daha etkin kullanmaya yönelik değişimleri ile dikkat çekici bir ülke konumundadır. Geçişin etkilerinin daha da kuvvetlendiği yıllardan olan 2007 yılında yine geçişin erken dönemlerinde olduğu gibi
Macaristan'ın sağlık harcamalarının etkinliği konusunda en başarısız ülke olduğu görülmektedir. 2013 yılı hariç etkin olamayan Macaristan için Ek 2'de tablo halinde verilen her bir ülkenin referans ve yoğunluk değerleri kullanılmış ve 2007 yılı için hedef değerler ve mevcut girdi düzeylerinde yaşanacak değişimler hesaplanmıştır.

Tablo 6: Macaristan'a Ait 2007 Yılı Girdileri için İyileştirme Değerleri

\begin{tabular}{|l|c|c|c|c|}
\hline & Gerçekleşen & Olması Gereken & Fark & $\%$ \\
\hline Bin kişi başına düşen doktor s. & 2,783 & 2,110101723 & $-0,672898277$ & $-24,18 \%$ \\
\hline Bin kişi başına düşen hastane yatağı S. & 7,1 & 5,271635176 & $-1,828364824$ & $-25,75 \%$ \\
\hline Kişi başına düşen sağlık harcaması & 1450,649273 & 1366,207222 & $-84,44205066$ & $-5,82 \%$ \\
\hline Bağışılık kazandırma oranı & 99 & 93,23722662 & $-5,762773381$ & $-5,82 \%$ \\
\hline
\end{tabular}

Tablo 6'da da görüldüğü üzere 2000 yılında olduğu gibi 2007 yılında da Macaristan için girdi kullanımının tasarrufuna yönelik öneriler ortaya çıkmıştır. Kurulan model tasarruf modeli olması sebebiyle de bu istenen bir durumdur. Bu değerler bir sonraki yıl için Macaristan'a öneri mahiyetinde en az maliyetle en iyi çıktı değerlerini elde etme olanağı verecek değerlerdir ki ülke yöneticilerinin bu önerileri dikkate alıp almamaları o dönemin şartlarına göre ve yönetim anlayışlarına göre de değişiklik göstermektedir. Bin kişi başına düşen doktor sayısında \%24 lük bir azaltıma gidilmesi, bin kişi başına düşen hastane yatağı sayısının \%25 oranında azaltımı, kişi başına düşen sağlık harcamalarının \% 5 oranında ve bağışıklık kazandırma faaliyetlerinin de $\% 5$ düşürülmesi sonucunda bebek ölüm oranının ve beklenen yaşam süresinin aynı oranda kalmasını sağlayabilecektir. Bu sonuçlar VZA'nın önerdiği rakamlar olmakla birlikte doktor sayısında istenen azaltımdan kasıt doktorların etkin- liğinin artırılmasına yönelik bir uyarı niteliği taşımaktadır. Kısaca bu noktada azaltım bir doktorun daha da fazla çalışarak daha çok hastaya daha etkin sağlık hizmeti sunması olarak da yorumlanabilmektedir. Karar mekanizmalarının vereceği kararlar bu aşamada önemlidir. Kaynakların etkin kullanılamaması durumu sermaye, işgücü ve malzeme gibi kayıplara yol açabilmektedir ki ilerleyen yıllarda zamanında alınmayan önlemler sağlık hizmetlerinde bir dar boğaz yaratabilir. Macaristan gibi etkin olmayan ülkelere ait iyileştirme değerleri hem 2000 hem de 2007 yılları için piyasa ekonomisi mantığını yansıtan benzer bulgular olması nedeniyle Ek 3 ve Ek 4'de tablolar halinde verilmiştir.

\section{SONUÇ}

Bu çalışma 90'lı yıllara kadar sağlık sistemleri farklı şekilde yönetilmiş ve SSCB'nin 1991 yılında dağılmasından hem ekonomik hem de sosyal açıdan etkilenmiş şimdinin geçiş ekonomili ülkeleri olarak adlandırı- 
lan ülkelerin sağlık harcamalarının etkinliğine yönelik bir analizdir. Analize uygun olduğu belirlenen girdi ve çıktı değişkenleri ile 2000-2013 yılları boyunca ülkelerin sağlık sistemleri göreceli olarak değerlendirilmeye alınmıştır. Kalkınmışlık düzeyinin göstergesi olması bakımından önem taşıyan sağlık sistemi üzerinde merkezi planlamacı devlet anlayışından serbest piyasa ekonomisi anlayışına geçişin ülkelerin sağlık sistemleri üzerinde ne gibi etkilerinin olduğunun ortaya konduğu bu çalışmada sağlık harcamalarının etkin yönetilip yönetilmediği VZA tekniği ile tespit edilmeye çalışıımışıır. Geçiş ekonomili ülkeler olarak adlandırılan ülkeler içerisinde 2004 ve 2007 yıllarında $A B^{\prime}$ ye üye olan 10 geçiş ülkesi sağlık sistemlerinde meydana gelen değişiklikleri daha iyi yansıtabildiği ve Dünya Bankası tarafından 2007 yılı itibariyle piyasa ekonomisine geçiş süreçlerini tamamladıkları ifade edildiği için homojen bir küme olarak değerlendirmeye alınmışlardır. VZA, ülkelerin sağlık sistemlerinin etkin olup olmadıklarını ülke karşılaştırmaları yaparak tespit etmektedir. Bu nedenle etkin çıkan ülkelerin en iyi sağlık sistemine sahip ülkeler olduklarını söylemek pek de doğru bir söylem olmamak ile birlikte modelde yer alan ülkelerin karşılaştırılarak göreli olarak etkin olup olmadıklarının tespit edilmesi ve bu tespitlere göre ülkelere ait çıkarımlarda bulunulması karar mekanizmalarına yardımcı olabilecek nitelikteki değerlendirmeleri sunmaktadır. VZA'nın girdi odaklı CCR modeli ile gerçekleştirilen analizde öncelikli olarak 2000-2006 yılları arasında piyasa ekonomisine geçiş sürecini yaşayan ve bu süreç içerisinde $A B^{\prime}$ ye üye olarak kabul edilen ülkelerin yıllar itibariyle girdilerini tasarruflu bir şekilde kullanıp kullanmadıkları göreceli olarak tespit edilmiştir. Etkin olmayan ülkelere referans olacak ülkelerin tespiti ile de girdi azaltımı ya da arttırımı konusunda hedeflenmesi gereken değerler tespit edilmiştir. Tüm bunlar ile karar mekanizmalarının yürüttüğü politikalar sonucu $A B^{\prime}$ ye üye olmayı başarmış ülkelerin 2007-2013 yılları arasındaki sağlık sistemlerine ilişkin göreceli etkinlik değerlendirmeleri yapılmıştır. Böylelikle geçiş süreci sırasında ve süreç bitimi sonrasında göreceli etkin olan ülkelerin farklılaşıp farklılaşmadığı belirlenmiştir. 2000-2006 yılları arası dönemde ülkelerin Ek 5 'te sunulan yıllar boyu etkinlik sıralamaları değerlendirildiğinde Slovenya, Estonya, Polonya ve Romanya'nın 7 yıllık dönemde sağlık sistemlerini etkin bir şekilde yönettiği; Bulgaristan, Çek Cumhuriyeti'nin ise zaman zaman etkin ama genel olarak etkin olmayan bir şekilde yıllarını geçirmiş olduğu tespit edilmiştir. Letonya, Litvanya, Macaristan, Slovakya ise 2000-2006 yılları arası dönemde etkin olmayan ülkeler olarak belirlenmişlerdir. Ek 6'da verilen ikinci 7 yıllık dönem için yapılan etkinlik sıralaması 2007-2013 yılları arasındaki dönemi kapsa- makta ve yine aynı homojenlikteki ülkeler arasındaki göreceli olarak en etkin ülkeleri tespit etmektedir. Bu tespitlere göre en etkin ülkeler Slovenya, Estonya, Romanya olmuştur. Polonya 2013 yılı hariç diğer yıllar etkin durumda iken, geçen 7 yıllık dönemde göreceli olarak hiç etkin olmayan ülke olan Letonya 2010 ve 2011 yıllarında en etkin ülke olarak tespit edilmiştir. Bu durum Letonya'nın Avrupa Komisyonu tahminlerine göre, Avrupa Birliği ve Euro alanında en hızlı büyüme yakalayan ülke olması ile tutarlıdır. Buna göre Litvanya'nın 2014 için 3.8, 2015 de 4.1 ile üyeler arasında en yüksek büyüme oranına sahip olması beklentisini karşılaşmaktadır. ${ }^{3}$ Ayrıca Bulgaristan'ın $A B$ üyesi olmadan önceki dönemlerinde girdi değişkenlerini diğer ülkelere göre daha etkin kullandığı ancak piyasa ekonomisine uyum süreci ile birlikte diğer ülkeler arasında sağlık sisteminin yönetimi açısından daha geride kaldığı sonucuna ulaşılmıştır. Macaristan'ın ise yıllar boyu aynı homojen küme içerisinde göreceli olarak girdilerini etkin kullanamadığı görülürken 2013 yılında ise sağlık harcamalarını etkin şekilde yöneten bir ülke konumuna ulaştığı ve böylece sürece dahil olduğunu görülmüştür. $A B^{\prime} y e$ üye olduktan sonraki dönem içerisinde de sağlık sistemleri açısından ülkeler bazında çok büyük farklılıklar görülmemiştir. Ancak istikrarın mevcut şartlarda her ülke açısından sağlanmış olduğu söylenebilmektedir. Karar mekanizmaları ekonomilerinin biçim değiştirmesine adapte olmak için yürüttükleri politikalar nezdinde sağlık sistemlerinin daha güçlü olmasını istemişlerdir. Ancak izledikleri politikalardaki eksiklikler nedeniyle istikrar sağlanmış gibi görünse de değişim sürecinde ve sonrasındaki pek çok ülkenin göreceli olarak sağlık sistemlerin hala tam olarak etkin olmadıkları tespit edilmiştir.

Günümüzde ekonomik gelişmeye insani bir boyut kazandırılması, gelişmişlik düzeyinde sağlık verilerinin de dikkate alınmasını gerektirmektedir. Dolayısıyla, ekonomik büyümenin sürekliliği bakımından çalışan nüfusun üretkenliğinin sağlanması amacıyla sağlık sisteminin etkin olması gerektiği düşüncesi sığ kalmaktadır, fakat büyüme olmadan gelişmenin sağlanamayacağı da kabul edilen bir savdır. Bu bakımdan koruyucu sağlık hizmetleri ile birlikte tedavi hizmetlerinin etkinliği, hastalıklardan korunma ve tedavi süreleri üzerinde etkili olması bireyin mutluluğu ile birlikte üretkenliğini de doğrudan etkiyeceği de göz ardı edilmemelidir. Bu bağlamda, sağlık harcamaları diğer kamu harcama kalemlerinden daha dikkatli ele alınmalı ve etkileri daha detaylı değerlendirilmelidir. 


\section{SON NOTLAR}

${ }^{1}$ Rudraswamy ve Doggalli (2012), sağlıkta geçiş ile geçiş ekonomilerindeki sağlık politikalarını ayrıştırmaktadir. Birinci kavram; daha önce merkezi planlamaya dayalı olan geçiş ekonomilerinde, geçiş sürecindeki kötüye giden birçok sağlık göstergesiyle ilgili durumu ifade etmektedir. İkinci terim ise belirli bir nüfusda ki sağlık ve hastalık kalıplarını anlamına gelmektedir.

${ }^{2}$ Çek Cumhuriyeti, Estonya, Macaristan, Letonya, , Litvanya, Polonya, Slovakya ve Slovenya geçiş dönemini tamamlamış ülkeler olarak ifade edilmektedir (Alam, Casero, Khan ve Udompsaph, 2008; Rudraswamy ve Doggalli; 2012). Çalışma esnasında bu durum dikkate alınmıştır.

${ }^{3}$ http://www.latvia.eu/tr/news/latvia-set-havehighest-gdp-growth-eu

\section{KAYNAKLAR}

Adeyi, O., Chellaraj, G. , Goldstein, E., Preker, A. ve Ringold, D. (1997) "Health Status During the Transition in Central and Eastern Europe: Development in Reverse" Health Policy Plan, 12(2):132-45.

Alam, A., Casero, P. , Khan, F. ve Udomsaph, C. (2008) "Unleashing Prosperity:Productivity Growth in Eastern Europe and the Former Soviet Union" The World Bank Report, 42.

Arslan, A. (2002) "Kamu Harcamalarında Verimlilik, Etkinlik ve Denetim” Maliye Dergisi,140.

Boussofiane, A., Dyson, R.G. ve Thanassoulis, E. (1991) "Applied Data Envelopment Analysis" European Journal Of Operational Research, 52(1):1-15.

Carvalho, A., Nepal, R. ve Jamasb, T. (2013), “Market-Oriented Structural Reforms and Human Development: Evidence from Transition Economies", School of Economics, University of Queenslands Discussion Paper Series, 593.

Charnes, A., Cooper, W.W. ve Rhodes, W. (1978) "Measuring Efficiency of Decision Making Units" European Journal of Operational Research, 2: 429-444.

Charnes, A., Cooper, W.W, Leiwen, A.Y. ve Seiford, L.M. (1994) "Data Envelopment Analysis" USA : Kluwer Academic Publishers.

Chubarova, T., Grigorieva, N. ve Mkhitaryan, L. (2013) "Health Care Reforms in the CIS: Comparative Analysis of Armenia and Russia" The 1st International Conference on Public Policy, Grenoble, France, 26-28 June.

Çelebi, K., Cura, S. (2013), “Etkinlik Göstergeleri Açısından Sağlık Sistemleri: Karşılaştırmalı Bir Analiz”, Maliye Dergisi, 164: 47-67
Dyson, R.G., Allen, R., Camanho, A.S, Podinovski, V.V., Sarrico, C.S. ve. Shale, E.A. "Pitfalls and Protocols in DEA" European Journal of Operational Research, 132(2):245-259.

Ensor, T. (2004), "Informal Payments for Health care in Transition Economies", Social Science \& Medicine 58: 237-246

Evans, D., Tandon, A., Murray, C. ve Lauer, J. (2001) "Comparative Efficiency of National Health Systems: Cross National Econometric Analysis” BMJ, 323.

Fakin, B. ve Crombrugghe, A.D. (1997) "Fiscal Adjustments In Transitions Economies Transfers and the Efficiency of Public Spending: A Comparison with OECD Countries" World Bank Policy Research Working Paper, No: 1803.

Gupta S., Verhoeven, M. ve Tiongson, E. (2001). Public Spending on Health Care and the Poor. IMF Working Papers, No:127.

Hollingsworth, B., Dawson, P.J., Maniadakis, N. (1999) "Efficiency measurement of health care: a review of non-parametric methods and applications" $\mathrm{He}$ alth Care Management Science,2(3):161-172.

Jacobs, R., Smith, P.C. ve Street, A. (2006) “Measuring Efficiency in Health Care" The United States of America: Cambridge University Press.

Joumard,I., Andre, C. ve Nicq,C. (2010) "Health Care Systems: Efficiency and Institutions", Working Papers, 25.

Kayalı, C. A., Kayalı, N. ve Kartal,B. (2004) "Veri Zarflama Analizinin Türk Sağlık Sektöründe Bir Uygulaması", Celal Bayar Üniversitesi S.B.E., 2(2): 67-89.

Kirigia, J.M., Asbu, E.Z., Greene, W. ve Emrouznejad, A. (2007) "Technical Efficiency, Efficiency Change, Technical Progress and Productivity Growth in the National Health Systems of Continental African Countries" Eastern Africa Social Science Research Review , 23(2):1940.

Kocaman, A., Mutlu, M., Bayraktar, D. ve Araz, Ö. (2012) "OECD Ülkelerinin Sağlık Sistemlerinin Analizi” Endüstri Mühendisliği Dergisi, 23(4):14-31.

Korkut, U. ve Buzogány, A. (2013) "Successful Transplants? Reform Governments and Health Care Policy Change in Slovenia, Slovakia \& Hungary", Paper for the ICPP Conference, Grenoble, 26-28 June .

Kumbhakar, S. (2004) "Efficiency of World Health Systems” http://www. economics.unsw.edu.au/RESEARCH/SEMINAR/Visitor/kumbhaker (07.02.2013)

Kutzin, J. (2010) "Conceptual Framework For Analysing Health Financing Systems and the Effects of 
Reforms" Implementing Health Financing Reform Lessons from Countries in Transition Observary Studies Series, 21.

Linna, M., Nordblad,A. ve Koivu,M. (2003) "Technical and Cost-efficiency of Oral Health Care Provision in Finnish Health Centres" Soc Sci Med, 56(2):343-353.

Liu, J., Ding, F. ve Lall, V. (2000) "Using Data Envelopment Analysis to Compare Suppliers for Supplier Selection and Performance Improvement" Supply Chain Management An International Journal, 5(3):143-150.

Mandl, U., Dierx, A., Ilkovitz, F. (2008) The Effectiveness and Efficiency of Public Spending. European Economy Economic Papers, No:31

Masiye, F. (2007) "Investigating Health System Performance: An Application of Data Envelopment Analysis to Zambia Hospitals" BMC Health Services Research, 7:58.

Mirmirani, S. (2008) "Health Care Efficiency in Transition Economies: An Application of Data Envelopment Analysis "International Business \& Economics Research Journal, 7(2): 47-56.

Nguyen, N. ve Frenk, J. (2011) "Health Policies in Transitions, Oxford Textbook of Public Health" https:// medtextfree.wordpress.com/2011/04/06/3-4-healthpolicies-in-transition-economies (02.06.2013)

Oxley, H. ve MacFarlan, M. (1995) "Health Care Reform: Controlling Spending and Increasing Efficiency" OECD Economic Studies, No: 24.

Paoli, F. (2012) "Health System Efficiency and Sustainability European Perspective" Eurohealth, 18(3):14-18.

Popescu, C., Asandului, L. Ve Fatulescu, P. (2014) "A Data Envelopment Analysis for Evaluating Romania's Health System" Procedia - Social and Behavioral Sciences, 109: 1185-1189.

Puenpatom, A. ve Rosenman, R. (2006) "Efficiency of Thai Provincial Public Hospitals After the Introduction of National Health Insurance Program" School of Economic Sciences, Washington State University, Working Paper Series, 2-33.

Retzlaff-Roberts, D., Chang, C.F. ve Rubin, R.M. (2004) "Technical Efficiency in the Use of Health Care Resources: A Comparison of OECD Countries" Health
Policy, 69(1):55-72.

Rudraswamy, S. ve Doggalli, N. (2012) "Health Policies in Transition Economics" Journal of Hospital Administration, 1: 1 .

Safaei, J (2012) "Communist Health Transitions in Central and Eastern Europe" Economics Research International, 2012 (2012).

Sherman, H.D. (1984) "Data Envelopment Analysis as a New Managerial Audit Methodology-Test and Evaluation" Auditing: A Journal of Practice and Theory, 4: 3553.

Smith, P. (2012) "What is the Scope for Health System, Efficiency Gains and How They can be Achieved", Eurohealth, 18(3): 3-7.

Stratmann T., Crivelli, E. ve Leive, A. (2010) "Subnational Health Spending and Soft Budget Constraints in OECD Countries "IMF Working Paper, 10:147.

Şenatalar, B. (2003) "Sağlık Ekonomisine Genel Bakış" Cumburiyet Üniversitesi T⿰p Fakültesi Dergisi, 25(4).

Şahin B. (1999) "Sağlığın Ölçümü ve Kullanım Alanlarına Teorik Bir Bakış” Sağlık ve Toplum Dergisi, 9(3): 3-12.

Tambori, M., Pavlova, M. Rechel, B., Golinowska, S. , Sowada, C. ve Groot, W. (2013) "The Inability to Pay for Health Services in Central and Eastern Europe: Evidence from Six Countries" European Journal of Public Health, 24(3):378-385.

United Nation (2013) World Economic Situation and Prospects Reports.

Wagener, H. (2011) "The Welfare State in Transition Economies and Accession to the EU" West European Politics, 25(2): 152-174

Yardım, M.S, Çilingiroğlu N ve Yardım, N (2010) "Catastrophic Health Expenditure and Impoverishment in Turkey " Health Policy, 94: 26-33.

Zhang, N., Hu, A., Zheng, J. (2007) "Using Data Envelopment Analysis Approach to Estimate the Health Production Efficiencies in China," Frontiers of Economics in China, 2(1): 1-23. 


\section{Ekler}

Ek-1: Ülkelerin 2000-2006 Yılları Arası Referans Ülkeleri ve Yoğunluk Değerleri

\begin{tabular}{|c|c|c|c|c|c|c|c|}
\hline & \multicolumn{7}{|c|}{ Referans Ülkeleri ve Yoğunluk Değerleri } \\
\hline & 2000 & 2001 & 2002 & 2003 & 2004 & 2005 & 2006 \\
\hline Bulgaristan & - & - & - & $\begin{array}{c}\text { Pol. } \\
\mathbf{0 , 6 4 1 9} \\
\text { Rom. } \\
\mathbf{0 , 3 3 9 0 4}\end{array}$ & - & $\begin{array}{c}\text { Pol. } \\
\mathbf{0 , 6 2 4 0 7} \\
\text { Rom. } \\
\mathbf{0 , 3 5 8 3 6}\end{array}$ & $\begin{array}{c}\text { Pol. } \\
\mathbf{0 , 1 5 2 0 6} \\
\text { Rom. } \\
\mathbf{0 , 7 5 1 4 9} \\
\text { Sloven. } \\
\mathbf{0 , 0 8 9 0 7}\end{array}$ \\
\hline Çek Cum. & - & - & $\begin{array}{c}\text { Est. } \\
\mathbf{0 , 5 1 0 3 7} \\
\text { Sloven. } \\
\mathbf{0 , 5 2 4 9 1}\end{array}$ & $\begin{array}{c}\text { Est. } \\
\mathbf{0 , 0 4 5 2} \\
\text { Pol. } \\
\mathbf{0 , 3 9 5 8 2} \\
\text { Sloven. } \\
\mathbf{0 , 5 5 1 8 8}\end{array}$ & $\begin{array}{c}\text { Est. } \\
\mathbf{0 , 2 3 0 6 5} \\
\text { Pol. } \\
\mathbf{0 , 2 3 2 6 3} \\
\text { Sloven. } \\
\mathbf{0 , 5 4 0 4 2}\end{array}$ & $\begin{array}{c}\text { Est. } \\
\mathbf{0 , 1 4 7 5 3} \\
\text { Pol. } \\
\mathbf{0 , 3 0 7 0 8} \\
\text { Sloven. } \\
\mathbf{0 , 5 4 3 5 8}\end{array}$ & $\begin{array}{c}\text { Est. } \\
\mathbf{0 , 3 2 4 5 8} \\
\text { Rom. } \\
\mathbf{0 , 1 2 9 4 8} \\
\text { Sloven. } \\
\mathbf{0 , 5 5 8 1 8}\end{array}$ \\
\hline Estonya & - & - & - & - & - & - & - \\
\hline Letonya & $\begin{array}{c}\text { Bul. } \\
\mathbf{0 , 6 6 6 9 2} \\
\text { Pol. } \\
\mathbf{0 , 3} \\
\text { Sloven. } \\
\mathbf{5 , 2 5 E - 0 3}\end{array}$ & $\begin{array}{c}\text { Bul. } \\
\mathbf{0 , 4 9 0 5 9} \\
\text { Pol. } \\
\mathbf{0 , 3 4 0 7 3} \\
\text { Rom. } \\
\mathbf{0 , 1 4 4 3 0}\end{array}$ & $\begin{array}{c}\text { Bul. } \\
\mathbf{0 , 5 1 5 5 3 1} \\
\text { Pol. } \\
\mathbf{0 , 3 3 1 3 4} \\
\text { Rom. } \\
\mathbf{0 , 1 2 9 9 4 3}\end{array}$ & $\begin{array}{c}\text { Pol. } \\
\mathbf{0 , 6 5 5 1 6} \\
\text { Rom. } \\
\mathbf{0 , 3 1 4 0 2} \\
\end{array}$ & $\begin{array}{c}\text { Bul. } \\
\mathbf{0 , 4 1 0 8 9} \\
\text { Pol. } \\
\mathbf{0 , 5 6 3 9 7}\end{array}$ & $\begin{array}{c}\text { Pol. } \\
\mathbf{0 , 9 4 1 8} \\
\text { Rom. } \\
\mathbf{0 , 0 1 0 0 9}\end{array}$ & $\begin{array}{c}\text { Rom. } \\
\mathbf{0 , 6 7 8 3 9} \\
\text { Sloven. } \\
\mathbf{0 , 2 8 0 5 9}\end{array}$ \\
\hline Litvanya & $\begin{array}{c}\text { Bul. } \\
\mathbf{1 , 0 0 4 9}\end{array}$ & $\begin{array}{c}\text { Bul. } \\
\mathbf{0 , 2 6 2 2 1} \\
\text { Est. } \\
\mathbf{0 , 1 2 8 6 6} \\
\text { Pol. } \\
\mathbf{0 , 5 9 0 2 9 5}\end{array}$ & $\begin{array}{c}\text { Bul. } \\
\mathbf{0 , 3 9 9 4 6 6} \\
\text { Est. } \\
\mathbf{0 , 5 3 4 0 1 2} \\
\text { Sloven. } \\
\mathbf{6 , 8 3 E - 0 2}\end{array}$ & $\begin{array}{c}\text { Pol. } \\
\mathbf{0 , 9 3 9 0 9} \\
\text { Sloven. } \\
\mathbf{0 , 0 2 6 1 1}\end{array}$ & $\begin{array}{c}\text { Bul. } \\
\mathbf{0 , 1 1 5 2 1 9} \\
\text { Pol. } \\
\mathbf{0 , 6 8 5 8 9} \\
\text { Rom. } \\
\mathbf{0 , 1 7 1 3 3}\end{array}$ & $\begin{array}{c}\text { Pol. } \\
\mathbf{0 , 9 0 9 9 2} \\
\text { Rom. } \\
\mathbf{0 , 0 4 1 9 2}\end{array}$ & $\begin{array}{c}\text { Est. } \\
\mathbf{0 , 1 3 2 2 2} \\
\text { Rom. } \\
\mathbf{0 , 6 0 5 5 0} \\
\text { Sloven. } \\
\mathbf{0 , 2 2 7 3 1}\end{array}$ \\
\hline Macaristan & $\begin{array}{c}\text { Bul. } \mathbf{0 , 6 1 7 4 5 2} \\
\text { Sloven. } \\
\mathbf{0 , 3 5 8 0}\end{array}$ & $\begin{array}{c}\text { Bul. } \\
\mathbf{0 , 6 2 9 5 3} \\
\text { Sloven. } \\
\mathbf{0 , 3 5 7 3}\end{array}$ & $\begin{array}{c}\text { Bul. } \\
\mathbf{0 , 5 8 0 0 7} \\
\text { Sloven. } \\
\mathbf{0 , 4 0 3 4 0}\end{array}$ & $\begin{array}{c}\text { Pol. } \\
\mathbf{0 , 4 7 2 3 7} \\
\text { Sloven. } \\
\mathbf{0 , 4 8 2 2 1}\end{array}$ & $\begin{array}{c}\text { Pol. } \\
\mathbf{0 , 5 2 2 7 5} \\
\text { Sloven. } \\
\mathbf{0 , 4 3 4 1 9}\end{array}$ & $\begin{array}{c}\text { Pol. } \\
\mathbf{0 , 4 9 3 6 6} \\
\text { Sloven. } \\
\mathbf{0 , 4 5 9 0 3 9}\end{array}$ & $\begin{array}{c}\text { Rom. } \\
\mathbf{0 , 4 0 9 0 1} \\
\text { Sloven. } \\
\mathbf{0 , 5 5 8 1 1}\end{array}$ \\
\hline Polonya & - & - & - & - & - & - & - \\
\hline Romanya & - & - & - & - & - & - & - \\
\hline Slovakya & $\begin{array}{c}\text { Bul. } \\
\mathbf{0 , 5 6 4 4 6} \\
\text { Çek C. } \\
\mathbf{0 , 1 2 0 1 3 4} \\
\text { Pol. } \\
\mathbf{0 , 2 6 0 7 1 8} \\
\text { Sloven. } \mathbf{5 , 7 9 E -} \\
\mathbf{0 2}\end{array}$ & $\begin{array}{c}\text { Bul. } \\
\mathbf{0 , 4 8 8 0 2 9} \\
\text { Pol. } \\
\mathbf{0 , 4 6 0 5 9 8} \\
\text { Sloven. } \\
\mathbf{5 , 5 5 E - 0 2}\end{array}$ & $\begin{array}{c}\text { Bul. } \\
\mathbf{0 , 4 9 9 3 1} \\
\text { Est. } \\
\mathbf{0 , 0 9 0 6} \\
\text { Pol. } \\
\mathbf{0 , 3 6 0 1} \\
\text { Sloven. } \\
\mathbf{0 , 0 5 8 8}\end{array}$ & $\begin{array}{c}\text { Pol. } \\
\mathbf{0 , 9 5 9 7 7} \\
\text { Sloven. } \\
\mathbf{0 , 0 2 6 1 3}\end{array}$ & $\begin{array}{c}\text { Pol. } \\
\mathbf{0 , 7 7 4 0 9} \\
\text { Sloven. } \\
\mathbf{0 , 2 0 7 5 0}\end{array}$ & $\begin{array}{c}\text { Pol. } \\
\mathbf{0 , 7 3 6 5 0} \\
\text { Sloven. } \\
\mathbf{0 , 2 4 0 5 7}\end{array}$ & $\begin{array}{c}\text { Rom. } \\
\mathbf{0 , 5 0 8 9} \\
\text { Sloven. } \\
\mathbf{0 , 4 7 9 9 9}\end{array}$ \\
\hline Slovenya & - & - & - & - & - & - & - \\
\hline
\end{tabular}


Ek-2: Ülkelerin 2007-2013 Yılları Arasına Referans Ülkeleri ve Yoğunluk Değerleri

\begin{tabular}{|c|c|c|c|c|c|c|c|}
\hline & \multicolumn{7}{|c|}{ Referans Ülkeleri ve Yoğunluk Değerleri } \\
\hline & 2007 & 2008 & 2009 & 2010 & 2011 & 2012 & 2013 \\
\hline Bulgaristan & $\begin{array}{l}\text { Pol. 0,46695 } \\
\text { Rom. } \\
\text { 0,51716 }\end{array}$ & - & $\begin{array}{l}\text { Est. } 0,31128 \\
\text { Rom. } \\
0,68368\end{array}$ & $\begin{array}{l}\text { Let. } \\
0,58918 \\
\text { Rom. } \\
0,41135\end{array}$ & $\begin{array}{l}\text { Let. } \\
0,58118 \\
\text { Rom. } \\
0,42116\end{array}$ & $\begin{array}{l}\text { Est. } \\
0,16926 \text { Let. } \\
0,59427 \\
\text { Rom. } \\
0,23516\end{array}$ & $\begin{array}{l}\text { Rom. } \\
0,74298 \\
\text { Sloven. } \\
0,23745\end{array}$ \\
\hline Çek Cum. & $\begin{array}{l}\text { Est. } \\
0,33314 \text { Pol. } \\
0,15290 \\
\text { Sloven. } \\
0,52141\end{array}$ & - & $\begin{array}{l}\text { Est. } 0,43186 \\
\text { Rom. } \\
0,56684\end{array}$ & $\begin{array}{l}\text { Est. } 0,19764 \\
\text { Let. } 0,27161 \\
\text { Sloven. } \\
0,53584\end{array}$ & $\begin{array}{l}\text { Est. } 0,22963 \\
\text { Let. } \\
0,219804 \\
\text { Sloven. } \\
0,55266\end{array}$ & $\begin{array}{l}\text { Est. } \\
0,08316 \text { Let. } \\
0,31361 \\
\text { Sloven. } \\
0,60633\end{array}$ & $\begin{array}{l}\text { Est. } \\
0,02048, \\
\text { Rom. } \\
0,25329 \\
\text { Sloven. } \\
0,72017\end{array}$ \\
\hline Estonya & - & - & - & - & - & - & - \\
\hline Letonya & $\begin{array}{l}\text { Pol. } \\
0,811603 \\
\text { Sloven. } \\
0,12667\end{array}$ & $\begin{array}{l}\text { Bul. } \\
0,20988 \text { Est. } \\
0,46029 \text { Pol. } \\
0,30645\end{array}$ & $\begin{array}{l}\text { Est. } \\
0,35919 \\
\text { Rom. } \\
0,59474 \\
\text { Sloven. } \\
0,03296\end{array}$ & - & - & - & $\begin{array}{l}\text { Rom. } \\
0,78157 \\
\text { Sloven. } \\
0,19562\end{array}$ \\
\hline Litvanya & $\begin{array}{l}\text { Pol. } 0,864404 \\
\text { Sloven. } \\
0,07458\end{array}$ & $\begin{array}{l}\text { Bul. 0,12789 } \\
\text { Est. } 0,84691 \\
\text { Rom. } \\
\text { 5,40E-05 }\end{array}$ & $\begin{array}{l}\text { Est. } \\
0,87794 \\
\text { Rom. } \\
0,09853\end{array}$ & $\begin{array}{l}\text { Est. } 0,27252 \\
\text { Let. } \\
0,63729 \\
\text { Sloven. } \\
0,07311\end{array}$ & $\begin{array}{l}\text { Est. } 0,27828 \\
\text { Let. } \\
0,61483 \\
\text { Sloven. } \\
0,08896\end{array}$ & $\begin{array}{l}\text { Est. } 0,25995 \\
\text { Let. } \\
0,58794 \\
\text { Sloven. } \\
0,13254\end{array}$ & $\begin{array}{l}\text { Est. } \\
0,17964, \\
\text { Rom. } \\
0,46549 \\
\text { Sloven. } \\
0,32001\end{array}$ \\
\hline Macaristan & $\begin{array}{l}\text { Pol. 0,63565 } \\
\text { Sloven. } \\
0,32233\end{array}$ & $\begin{array}{l}\text { Est. } \\
0,62364 \text { Pol. } \\
0,20858 \\
\text { Sloven. } \\
0,15159\end{array}$ & $\begin{array}{l}\text { Est. } 0,68624 \\
\text { Rom. } \\
0,09754 \\
\text { Sloven. } \\
0,19509\end{array}$ & $\begin{array}{l}\text { Let. } 0,63092 \\
\text { Sloven. } \\
0,35061\end{array}$ & $\begin{array}{l}\text { Let. } \\
0,58658 \\
\text { Rom. } \\
0,06804 \\
\text { Sloven. } \\
0,33297\end{array}$ & $\begin{array}{l}\text { Pol. } \\
0,20996 \\
\text { Rom. } \\
0,34715 \\
\text { Sloven. } \\
0,41253\end{array}$ & - \\
\hline Polonya & - & - & - & - & - & - & $\begin{array}{l}\text { Macar. } \\
0,08004 \\
\text { Rom. } \\
0,57275 \\
\text { Sloven. } \\
0,35025\end{array}$ \\
\hline Romanya & - & - & - & - & - & - & - \\
\hline Slovakya & $\begin{array}{l}\text { Pol. 0,49812 } \\
\text { Sloven. } \\
0,46749\end{array}$ & $\begin{array}{l}\text { Est. } \\
0,50389 \text { Pol. } \\
0,05256 \\
\text { Sloven. } \\
0,42611\end{array}$ & $\begin{array}{l}\text { Est. } \\
0,41806 \\
\text { Sloven. } \\
0,55246\end{array}$ & $\begin{array}{l}\text { Let. } 0,27483 \\
\text { Sloven. } \\
0,69053\end{array}$ & $\begin{array}{l}\text { Let. } 0,66831 \\
\text { Sloven. } \\
0,33497\end{array}$ & $\begin{array}{l}\text { Est. } 0,21054 \\
\text { Let. } \\
0,26429 \\
\text { Sloven. } \\
0,50572\end{array}$ & $\begin{array}{l}\text { Est. } \\
0,45924, \\
\text { Rom. } \\
0,01238 \\
\text { Sloven. } \\
0,50014\end{array}$ \\
\hline Slovenya & - & - & - & - & - & - & - \\
\hline
\end{tabular}


Ek 3. 2000 Yılına Ait Etkin Olmayan Ülkelerin İyileştirme Dereceleri

\begin{tabular}{|c|c|c|c|c|}
\hline LETONYA & Gerçekleşen & Olması Gereken & Fark & $\%$ \\
\hline Bin kişi başına düşen doktor s. & 3,204 & 2,938267 & $-0,26573$ & $-8,29 \%$ \\
\hline Bin kişi başına düşen hastane yatağı s. & 8,73 & 6,440415 & $-2,28958$ & $-26,23 \%$ \\
\hline Kişi başına düşen sağlık harcaması & 479,1415 & 439,4025 & $-39,739$ & $-8,29 \%$ \\
\hline Bağışıklık kazandırma oranı & 97 & 88,95503 & $-8,04497$ & $-8,29 \%$ \\
\hline LITVANYA & Gerçekleşen & Olması Gereken & Fark & $\%$ \\
\hline Bin kişi başına düşen doktor s. & 4,01 & 3,41589 & $-0,59411$ & $-14,82 \%$ \\
\hline Bin kişi başına düşen hastane yatağı s. & 9,76 & 7,44682 & $-2,31318$ & $-23,70 \%$ \\
\hline Kişi başına düşen sağlık harcaması & 559,5763 & 386,9086 & $-172,668$ & $-30,86 \%$ \\
\hline Bağışıklık kazandırma oranı & 97 & 89,44224 & $-7,55776$ & $-7,79 \%$ \\
\hline SLOVAKYA & Gerçekleşen & Olması Gereken & Fark & $\%$ \\
\hline Bin kişi başına düşen doktor s. & 3,2 & 3,026282 & $-0,17372$ & $-5,43 \%$ \\
\hline Bin kişi başına düşen hastane yatağı s. & 7,9 & 6,831747 & $-1,06825$ & $-13,52 \%$ \\
\hline Kişi başına düşen sağlık harcaması & 604,1054 & 571,3104 & $-32,795$ & $-5,43 \%$ \\
\hline Bağışıklık kazandırma oranı & 98 & 92,67988 & $-5,32012$ & $-5,43 \%$ \\
\hline
\end{tabular}

Ek 4. 2007 Yılına Ait Etkin Olmayan Ülkelerin İyileştirme Dereceleri

\begin{tabular}{|c|c|c|c|c|}
\hline BULGARISTAN & Gerçekleşen & Olması Gereken & Fark & $\%$ \\
\hline Bin kişi başına düşen doktor s. & 3,665 & 2,521805 & $-1,143195$ & $-31,19 \%$ \\
\hline Bin kişi başına düşen hastane yatağı s. & 6,4011 & 6,15277 & $-0,24833$ & $-3,88 \%$ \\
\hline Kişi başına düşen sağlık harcaması & 841,0533 & 840,403 & $-0,650308$ & $-0,08 \%$ \\
\hline Bağışıklık kazandırma oranı & 96 & 95,92577 & $-7,42 \mathrm{E}-02$ & $-0,08 \%$ \\
\hline ÇEK CUMHURIYETI & Gerçekleşen & Olması Gereken & Fark & $\%$ \\
\hline Bin kişi başına düşen doktor s. & 3,61 & 2,716733 & $-0,893267$ & $-24,74 \%$ \\
\hline Bin kişi başına düşen hastane yatağı s. & 8,1 & 5,219829 & $-2,880171$ & $-35,56 \%$ \\
\hline Kişi başına düşen sağlık harcaması & 1665,23 & 1648,588 & $-16,64262$ & $-1,00 \%$ \\
\hline Bağışıklık kazandırma oranı & 98 & 97,02057 & $-0,97943$ & $-1,00 \%$ \\
\hline LETONYA & Gerçekleşen & Olması Gereken & Fark & $\%$ \\
\hline Bin kişi başına düşen doktor s. & 3,039 & 1,996663 & $-1,042337$ & $-34,30 \%$ \\
\hline Bin kişi başına düşen hastane yatağı s. & 7,6 & 5,391924 & $-2,208076$ & $-29,05 \%$ \\
\hline Kişi başına düşen sağlık harcaması & 1197,883 & 1132,4 & $-65,48304$ & $-5,47 \%$ \\
\hline Bağışıklık kazandırma oranı & 97 & 91,69743 & $-5,302565$ & $-5,47 \%$ \\
\hline LITVANYA & Gerçekleşen & Olması Gereken & Fark & $\%$ \\
\hline Bin kişi başına düşen doktor s. & 3,807 & 1,978834 & $-1,828166$ & $-48,02 \%$ \\
\hline Bin kişi başına düşen hastane yatağı s. & 8,1 & 5,459141 & $-2,640859$ & $-32,60 \%$ \\
\hline Kişi başına düşen sağlık harcaması & 1136,56 & 1076,463 & $-60,09688$ & $-5,29 \%$ \\
\hline Bağışıklık kazandırma oranı & 97 & 91,87102 & $-5,128985$ & $-5,29 \%$ \\
\hline SLOVAKYA & Gerçekleşen & Olması Gereken & Fark & $\%$ \\
\hline Bin kişi başına düşen doktor s. & 3,059 & 2,179755 & $-0,879245$ & $-28,74 \%$ \\
\hline Bin kişi başına düşen hastane yatağı s. & 6,8 & 5,141106 & $-1,658894$ & $-24,40 \%$ \\
\hline Kişi başına düşen sağlık harcaması & 1619,034 & 1532,28 & $-86,75399$ & $-5,36 \%$ \\
\hline Bağışıklık kazandırma oranı & 99 & 93,6952 & $-5,304797$ & $-5,36 \%$ \\
\hline
\end{tabular}


Ek 5. : 2000-2006 Yılları Arası Dönemde Ülkelerin Etkinlik Sıralaması

\begin{tabular}{|c|c|c|c|c|c|c|c|}
\hline & $\begin{array}{c}2000 \\
\text { Sira no }\end{array}$ & $\begin{array}{c}2001 \\
\text { Sira no }\end{array}$ & $\begin{array}{l}2002 \\
\text { Sira no }\end{array}$ & $\begin{array}{l}2003 \\
\text { Sira no }\end{array}$ & $\begin{array}{c}2004 \\
\text { Sira no }\end{array}$ & $\begin{array}{l}2005 \\
\text { Sira no }\end{array}$ & $\begin{array}{c}2006 \\
\text { Sira no }\end{array}$ \\
\hline Bulgaristan & 1 & 1 & 2 & 5 & 3 & 5 & 6 \\
\hline Çek Cumhuriyeti & 4 & 6 & 6 & 6 & 6 & 6 & 5 \\
\hline Estonya & 5 & 4 & 3 & 4 & 5 & 4 & 3 \\
\hline Letonya & 9 & 9 & 9 & 9 & 9 & 7 & 8 \\
\hline Litvanya & 8 & 7 & 8 & 8 & 7 & 9 & 9 \\
\hline Macaristan & 10 & 10 & 10 & 10 & 10 & 10 & 10 \\
\hline Polonya & 3 & 2 & 4 & 1 & 1 & 1 & 4 \\
\hline Romanya & 6 & 5 & 5 & 3 & 4 & 3 & 2 \\
\hline Slovakya & 7 & 8 & 7 & 7 & 8 & 8 & 7 \\
\hline Slovenya & 2 & 3 & 1 & 2 & 2 & 2 & 1 \\
\hline
\end{tabular}

Ek 6. 2007-2013 Yılları Arası Ülkelerin Etkinlik Sıralaması

\begin{tabular}{|l|c|c|c|c|c|c|c|}
\hline & 2007 & 2008 & 2009 & 2010 & 2011 & 2012 & 2013 \\
\hline & Sıra no & Sıra no & Sıra no & Sıra no & Sıra no & Sıra no & Sıra no \\
\hline Bulgaristan & 5 & 4 & 5 & 7 & 7 & 6 & 7 \\
\hline Çek Cumhuriyeti & 6 & 6 & 6 & 6 & 6 & 8 & 9 \\
\hline Estonya & 4 & 1 & 1 & 3 & 4 & 2 & 3 \\
\hline Letonya & 9 & 7 & 8 & 1 & 1 & 3 & 8 \\
\hline Litvanya & 7 & 8 & 7 & 8 & 8 & 7 & 6 \\
\hline Macaristan & 10 & 9 & 9 & 10 & 10 & 9 & 4 \\
\hline Polonya & 1 & 2 & 4 & 5 & 5 & 5 & 5 \\
\hline Romanya & 3 & 5 & 3 & 4 & 3 & 4 & 2 \\
\hline Slovakya & 8 & 10 & 10 & 9 & 9 & 10 & 10 \\
\hline
\end{tabular}


